http://journal.lldikti9.id/plenojure

Vol. 9, No. 1, April 2020, pp. 1-15

p-ISSN: 2301-7686 dan e-ISSN: 2684-8449

DOI: https://doi.org/10.37541/plenojure.v9i1.305

\title{
Gagasan Penyempurnaan Lembaga Majelis Permusyawaratan Rakyat Republik Indonesia dalam Sistem Parlemen Dua Kamar
}

\author{
Rizki Ramadani \\ Fakultas Hukum, Universitas Muslim Indonesia \\ Email Correspondensi: rizkiramadani@umi.ac.id \\ No. HP Correspondensi: +62 821-3793-2246
}

\begin{tabular}{|c|c|}
\hline Artikel info & \\
\hline 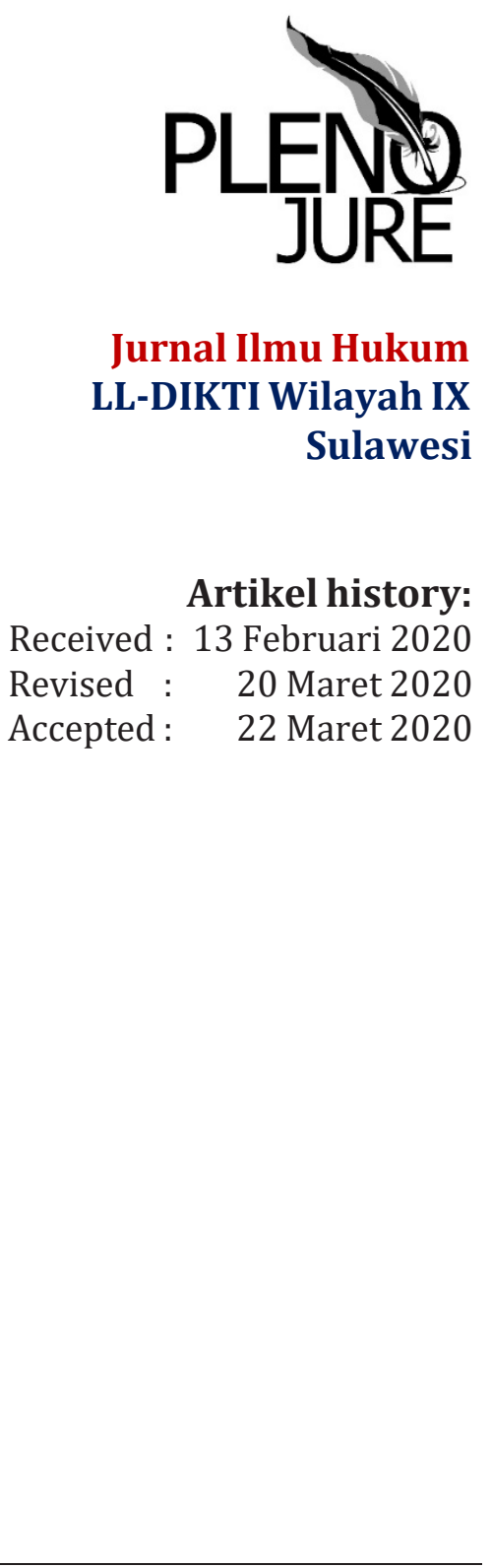 & $\begin{array}{l}\text { Abstrak. Berdasarkan Pasal } 1 \text { ayat (2) UUD } 1945 \\
\text { Sebelum Perubahan dan Penjelasannya, kekuasaan } \\
\text { Negara yang tertinggi ada di tangan MPR. Sejak itu } \\
\text { telah ada pengakuan bahwa MPR merupakan Lembaga } \\
\text { Tertinggi Negara, bahkan sebagai penjelmaan seluruh } \\
\text { rakyat Indonesia. Pasca Amandemen, UUD NRI Tahun } \\
1945 \text { resmi menganut pemisahan kekuasaan dengan } \\
\text { 'checks and balances'yang lebih fungsional. Implikasinya, } \\
\text { MPR kehilangan sebagian fungsi dan wewenangnya, } \\
\text { dan tidak lagi berkedudukan sebagai lembaga tertinggi } \\
\text { negara. Kini, bersamaan dengan munculnya wacana } \\
\text { amandemen kelima, timbul pula pembicaraan untuk } \\
\text { mereformulasi peran dan kelembagaan MPR. Artikel } \\
\text { ini berupaya merespon wacana secara objektif dengan } \\
\text { berupaya memunculkan gagasan penyempurnaan MPR } \\
\text { dengan pendekatan konsep parlemen dua kamar. Gagasan } \\
\text { tersebut adalah melalui penegasan posisi kelembagaan } \\
\text { MPR dalam sistem parlemen dua kamar dan perimbangan } \\
\text { kekuasaan antar kamar. } \\
\text { Abstract. The Based on Article } 1 \text { paragraph (2) of } \\
\text { the } 1945 \text { Constitution Before the Amendment and its } \\
\text { Elucidation, the highest state power is in the hands of the } \\
\text { MPR. Since then there has been recognition that the MPR } \\
\text { is the Supreme State Institution, even as the manifestation } \\
\text { of all the people of Indonesia. After the Amendment, the } \\
\text { 1945 Constitution of the Republic of Indonesia officially } \\
\text { adopted a more functional separation of powers with } \\
\text { more functional checks and balances, making the MPR } \\
\text { lost the vital parts of its functions and authority, and no } \\
\text { longer has the position of the highest state institution. } \\
\text { Now, along with the emergence of the discourse of the } \\
\text { fifth amendment, discussions also emerged to reform the } \\
\text { role and institutions of the MPR. This article attempts } \\
\text { to respond to the discourse objectively by trying to } \\
\text { come up with the idea of perfecting the MPR with the } \\
\text { concept of a two-chamber parliamentary approach. The } \\
\text { ideas were, through the affirmation of the institutional }\end{array}$ \\
\hline
\end{tabular}


Pleno Jure, Vol. 9 (1), Rizki Ramadani, Gagasan Penyempurnaan Lembaga ...

Keywords:

Majelis

Permusyawaratan

Rakyat;

Parlemen

Sistem Dua Kamar. position of the MPR in the two-chamber parliamentary system and the balance of powers between chambers.

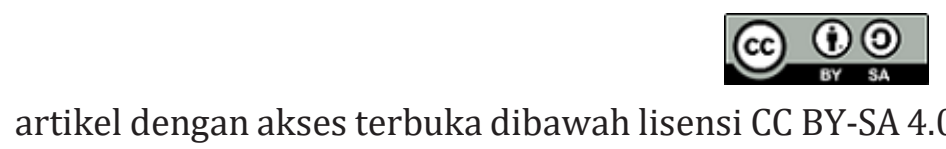

artikel dengan akses terbuka dibawah lisensi CC BY-SA 4.0

\section{PENDAHULUAN}

Sebagaimana yang dikemukakan oleh Jimly Asshiddiqie, terlepas dari pro dan kontranya, kita mesti mengakui bahwa Majelis Permusyawaratan Rakyat Republik Indonesia (MPR) merupakan lembaga negara orisinil yang lahir sesuai dengan budaya masyarakat Indonesia yang kental dengan suasana musyawarahnya. Adapun lembaga negara lain seperti Presiden, Badan Pemeriksa Keuangan Republik Indonesia (BPK), Mahkamah Agung Republik Indonesia (MA), Kepolisian Negara Republik Indonesia (Polri), ataupun Kejaksaan Republik Indonesia, kesemuanya merupakan lembaga "warisan" Belanda atau adopsi dari praktik negara lain. Hal ini dikarenakan belum ada lembaga yang sejenis MPR pada saat Indonesia di bawah kekuasaan Belanda (Hindia Belanda). Lembaga-lembaga negara semacam Dewan Perwakilan Rakyat Republik Indonesia (DPR) dapat dihubungkan dengan Volksraad (Dewan Rakyat), Presiden dapat dianggap sebagai pengganti lembaga Gouverneur General, MA berkaitan dengan Landraad dan Raad van Justitie pada zaman Hindia Belanda, serta Hogeraad seperti yang ada di negara Belanda. BPK serupa dengan Raad van Rekenkamer, sementara itu DPA dapat dikatakan berasal dari Raad van Nederlandshce Indie seperti yang ada di Batavia atau Raad van State seperti yang ada di negara Belanda. ${ }^{1}$

Pada awal era Reformasi (1999 - 2002), kedudukan MPR merupakan lembaga tertinggi negara dengan kekuasaan yang sangat besar. Hal tersebut mengacu pada Pasal 1 ayat (2) Undang-Undang Dasar Tahun 1945 sebelum perubahan (selanjutnya disebut UUD 1945), yang mengatur bahwa "Kedaulatan adalah di tangan rakyat, dan dilakukan sepenuhnya oleh Majelis Permusyawaratan Rakyat". ${ }^{2}$ Namun setelah bergulirnya pendulum kekuasaan dari orde baru ke era reformasi, konstitusi pun diubah dan menghasilkan Undang-Undang Dasar Negara Republik Indonesia Tahun 1945 pasca amandemen (selanjutnya disebut UUD NRI Tahun 1945). Menurut UUD NRI Tahun 1945, semua lembaga negara kedudukannya sejajar. UUD NRI Tahun 1945 tidak lagi menempatkan MPR sebagai lembaga tertinggi negara dan sebagai pelaku sepenuhnya kedaulatan rakyat. $^{3}$

${ }^{1}$ Asshiddiqie, J. (2005). Konstitusi dan Konstitusionalisme Indonesia. Jakarta: Konstitusi Press, hlm. 168.

${ }^{2}$ Rohmat, A. M. (2016). Kedudukan dan Kewenangan Majelis Permusyawaratan Rakyat dalam Era Reformasi. Jurnal Pembaharuan Hukum, Universitas Islam Sultan Agung, 3(2), hlm. 181.

${ }^{3}$ Widayati, W., Absori, A., \& Azhari, A. F. (2014). Rekonstruksi Kedudukan Ketetapan MPR dalam Sistem Ketatanegaraan Indonesia. Media Hukum, Universitas Muhammadiyah Yogyakarta, 21(2), hlm. 264. 
Dinamika politik dan hukum yang terjadi di MPR antara tahun 1999 - 2002 untuk mengamandemen UUD 1945 tidaklah sederhana dan mudah. Sebelumnya muncul berbagai perdebatan dan pro kontra, bahkan setelah amandemen tersebut disahkan hingga pada hari ini. Perjuangan masa itu bisa dikatakan merupakan awal dari desakralisasi terhadap UUD 1945 sebagai Konstitusi negara. Walaupun mesti diakui, masih ada banyak kekurangan yang mengemuka. Salah satunya dikemukakan oleh Denny Indrayana yang mengkritik proses perubahan yang pragmatis dan menghasilkan produk yang sarat kelemahan dari segi ketatanegaraan.

Susunan MPR dalam UUD NRI Tahun 1945 misalnya, ternyata memunculkan berbagai spekulasi mengenai sistem parlemen di Indonesia, apakah menganut sistem unicameral (satu kamar), bicameral (dua kamar) atau bahkan tricameral (tiga kamar). ${ }^{4}$ Berbagai spekulasi dan penafsiran yang timbul akibat susunan lembaga MPR di Indonesia dapat dimaklumi. Pasalnya, jika dilihat dari perspektif kelembagaan, struktur parlemen Indonesia dapat dikategorikan sebagai sistem dua kamar, tetapi apabila dilihat secara fungsional dalam pembuatan perundangundangan, cenderung dikategorikan sebagai sistem satu kamar mengingat dominasi kekuasaan legislasi oleh DPR. ${ }^{5}$ Faktanya, tidak sedikit pula pakar yang menilai lembaga perwakilan Indonesia menganut ciri khas tersendiri sebagai sistem tiga kamar. ${ }^{6}$ Antara lain dengan merujuk pada tugas dan kewenangan MPR yang secara khusus diatur dalam UUD NRI Tahun 1945 dan berbeda dengan tugas dan kewenangan DPR dan Dewan Perwakilan Daerah (DPD). ${ }^{7}$

UUD NRI Tahun 1945 baik kelembagaan, pengisian jabatan, maupun kewenangan MPR berubah secara drastis, sehingga seperti yang dikatakan oleh Mochtar Kusumaatmadja, banyak pihak "bernostalgia" hendak menempatkan kembali MPR sebagai lembaga negara "produk lokal" Indonesia. ${ }^{8}$ Apalagi jika ditilik kurun waktu UUD NRI Tahun 1945 yang telah berusia 14 tahun, banyak hal yang perlu dikoreksi hingga diperkuat dalam upaya menghadirkan UUD NRI Tahun 1945 sebagai the people constitution, hal tersebut semakin menguatkan gagasan amandemen kelima terhadap UUD NRI Tahun 1945. ${ }^{9}$ Munculnya gagasan untuk "memulihkan" Kelembagaan MPR melalui amandemen kelima UUD NRI Tahun 1945 juga terlihat dengan

${ }^{4}$ Bahkan berdasarkan studi terhadap beberapa konstitusi di dunia, bahwa parlemen dapat memiliki satu kamar (unicameralilsme), 2 kamar (bicameralism), 3 kamar (tricameralisme), 4 kamar (tetracameralisme), dan 5 kamar (pentacameralisme).

${ }^{5}$ Lihat ketentuan Pasal 20, Pasal 20A ayat (1) dan Pasal 21 UUD NRI Tahun 1945.

${ }^{6}$ Lihat Falaakh, M. F. (2002, 19 April). Metamorfosis MPR (Teka-Teki Parlemen Berkamar Tiga), dalam Harian Kompas, hlm. 4; Susanti, B. (2009). Lembaga Perwakilan Rakyat Trikameral, Supremasi DPR dan Sempitnya Ruang Demokrasi Perwakilan: Isi dan Implikasi UU Susduk dan Cermin Carut Marutnya Konstitusi. In A. R. M. \& L. Bakry (Eds.), Politik dan Pemerintahan Indonesia (hlm. 440 - 456). Jakarta: Masyarakat Ilmu Pemerintahan Indonesia; dan Isra, S. (2004). Penataan Lembaga Perwakilan Rakyat: Sistem Trikameral di Tengah Supremasi Dewan Perwakilan Rakyat. Jurnal Konstitusi, Mahkamah Konstitusi RI, 1(1).

${ }^{7}$ Lihat ketentuan Pasal 3 UUD NRI Tahun 1945.

${ }^{8}$ Kusumaatmadja, M. (2002). Konsep-Konsep Hukum dalam Pembangunan (O. Salman \& E. Damian Eds.). Bandung: PT. Alumni., hlm. 3 - 4.

${ }^{9}$ Nggilu, N. M. (2017, September). "Membaca" Kedudukan dan Kewenangan MPR dalam Sistem Ketatanegaraan Indonesia (Sebuah Kontemplasi Menuju Amandemen Kelima). Makalah dipresentasikan pada Seminar Nasional, diselenggarakan oleh Majelis Permusyawaratan Rakyat RI, di Jakarta, hlm. 1. 
intensnya penelitian dan pengkajian yang diinisiasi oleh Lembaga Kajian MPR dengan melibatkan institusi Perguruan Tinggi yang ada di Indonesia, dengan fokus terhadap isu-isu ketatanegaraan khususnya terkait dengan amandemen kelima UUD NRI Tahun $1945 .^{10}$

Di antara beberapa gagasan yang mengemuka dalam hingar-bingar wacana amandemen kelima tersebut adalah perlunya mengembalikan kedudukan dan kewenangan MPR. Mengingat wacana ini santer dihembuskan oleh para politisi, hal tersebut dirasa sangat tendensius. Meskipun di lain pihak, ada rasionalisasi bahwa MPR merupakan lembaga manifestasi dari sila keempat Pancasila, namun tidak memiliki peranan dan kontribusi yang signifikan dalam kancah ketatanegaraan dan pembangunan nasional hari ini. Hal ini seperti berbalik seratus delapan puluh derajat dari kondisi MPR sebelum amandemen UUD 1945 pada tahun 1999 - 2002. Oleh sebab itu, bagi kalangan yang pro terhadap penguatan kedudukan MPR, memunculkan wacana untuk mereposisi kedudukan MPR menjadi lembaga tertinggi negara, yang secara otomatis akan memiliki konsekuensi-konsekuensi lain dalam sistem ketatanegaraan. ${ }^{11}$

Berdasarkan uraian tersebut, seyogianya kita mesti menyikapi wacana reformulasi MPR dengan sikap yang tenang dan penuh kehati-hatian. Sebab, reaksi yang emosional dan insidentil bisa berdampak sistemik bagi kelembagaan MPR maupun aspek ketatanegaraan Indonesia secara keseluruhan. Artikel ini bermaksud untuk mengkaji permasalahan pokok tersebut dengan mengambil titik tolak pada masalah bagaimana gagasan penyempurnaan bagi lembaga MPR dalam sistem Parlemen dua kamar.

\section{METODE}

Penelitian ini merupakan penelitian normatif yang berfokus pada mengkaji peraturan perundang-undangan, asas-asas dan doktrin yang terkait dengan objek permasalahan yang dikaji. Penulis menggunakan pendekatan konseptual (conceptual approach), yang beranjak dari pandangan-pandangan dan doktrin-doktrin yang berkembang di dalam ilmu hukum.

\section{HASIL DAN PEMBAHASAN}

Sebagai suatu gagasan dalam penyempurnaan Lembaga perwakilan dalam konteks Indonesia, Penulis mengusulkan dua gagasan pokok, yakni: Pertama, Penegasan mengenai Jenis dan Kedudukan Kelembagaan MPR, dan Kedua, Perimbangan Kekuasaan antar kamar dalam parlemen. Gagasan ini akan diuraikan satu per satu secara lebih lanjut.

${ }^{10}$ Nggilu, N. M. (2014). Hukum dan Teori Konstitusi (Perubahan Konstitusi yang Partisipatif dan Populis). Yogyakarta: UII Press, hlm. 90.

${ }^{11}$ Asril, S. (2014, 29 September). MPR Ingin Amandemen UUD 1945, MPR Jadi Lembaga Tertinggi Negara dan Hidupkan GBHN. Dalam Kompas.com. Lebih lanjut, wacana ini kembali hangat belakangan ini dan dipelopori oleh salah satu partai pendukung pemerintah. Isu amandemen kelima kemudian lebih difokuskan pada pembicaraan tentang reformulasi kewenangan GBHN dan reposisi MPR sebagai lembaga tertinggi negara, di samping itu pula isu penguatan DPD yang timbul tenggelam. Putri, B. U. (2019, 8 Agustus). Anggota MPR: Ada yang Ingin Amandemen UUD 1945 ke Versi Pertama. Dalam Tempo.co. 


\section{A. Penegasan MPR sebagai Join Session dalam Sistem Parlemen Dua Kamar}

Berkaitan dengan struktur kelembagaan MPR, terjadi perdebatan yang panjang soal sistem yang dianut, apakah sistem parlemen satu kamar, dua kamar atau bahkan menjadi tiga kamar. Perubahan susunan MPR yang terdiri dari DPR dan DPD, seolah-olah mengarah pada pembentukan sistem parlemen dua kamar, tetapi dilihat dari susunan yang menyebutkan bahwa MPR terdiri dari anggota-anggota DPR dan DPD, tidak tergambar konsep dua kamar tersebut. ${ }^{12}$ Seolah-olah MPR merupakan wadah tunggal yang menaungi DPD dan DPR, namun melihat dari tugas dan kewenangannya yang diatur secara khusus dalam konstitusi, menimbulkan asumsi MPR sebagai entitas tersendiri di samping DPR dan DPD.

Pada tataran akademik dan politis, terdapat perbedaan pandangan atas tafsir Pasal 2 ayat (1) UUD NRI 1945 perihal keanggotaan MPR yang terdiri atas anggota Dewan Perwakilan Rakyat dan anggota Dewan Perwakilan Daerah. Secara umum pandangan tersebut terbagi atas dua: Pertama, pandangan yang menganggap MPR hanya sebagai Join Session antara DPR dan DPD sehingga parlemen cenderung pada sistem bicameral; dan Kedua, pandangan yang menyatakan bahwa MPR merupakan lembaga tersendiri di samping DPR dan DPD, sehingga lembaga perwakilan Indonesia pada dasarnya berbentuk tiga kamar atau trikameral.

Pandangan pertama bertolak pada argumentasi bahwa ada dua hal penting dalam ketentuan Pasal 2 ayat (1) di atas, antara lain yaitu: pertama, keanggotaan MPR bukan mewakili kelembagaan DPR dan DPD, tetapi merupakan keanggotaan perorangan. MPR hanya merupakan joint session saja untuk melakukan sidang-sidang dalam menjalankan kewenangan konstitusionalnya. Artinya MPR itu ada dan melaksanakan kewenangannya ketika dia bersidang mengubah atau menetapkan UUD NRI Tahun 1945, melantik Presiden dan/atau Wakil Presiden, dan memberhentikan Presiden dan/atau Wakil Presiden dalam masa jabatannya menurut UUD NRI Tahun 1945 dalam rangkaian akhir proses impeachment. ${ }^{13}$

Joint session biasanya terjadi ketika dua kelompok yang biasanya memutuskan suatu kebijakan secara terpisah, bertemu dalam suatu sesi yang luar biasa atau istimewa untuk melakukan tugas mereka bersamasama demi mencapai suatu tujuan tertentu. Join session di dalam Parlemen diidentikkan sebagai pertemuan dua buah lembaga legislatif (kamar) untuk mewujudkan suatu agenda bersama. Ketika dua kamar bertemu dalam sebuah joint session, maka kedua kamar itu bergabung menjadi satu dimana terdapat kuorum yang harus dipenuhi dari masing-masing kamar, kedua kamar memiliki bobot hak memilih (voting) yang sama, dan

\footnotetext{
${ }^{12}$ Widayati, W. (2015). Sistem Parlemen Berdasarkan Konstitusi Indonesia. Masalah-Masalah Hukum, Universitas Diponegoro, 44(4), hlm. 422.

${ }^{13}$ Risnain, M., \& Karyati, S. (2017). Menimbang Gagasan Perubahan Konstitusi dan Tata Cara Perubahan Konstitusi Republik Indonesia 1945. Jurnal Ius: Kajian Hukum dan Keadilan, Universitas Mataram, 5(1), hlm. 114.
} 
peraturan tertentu bisa diadopsi untuk mengatur jalannya joint session tersebut atau mereka bisa menjalankan joint session tersebut berdasarkan peraturan yang dianut oleh parlemen pada sistem hukum common law. ${ }^{14}$

Jika melihat kewenangan MPR dalam UUD NRI Tahun 1945, maka dapat dikatakan bahwa MPR adalah join session. Hal ini dikarenakan MPR bukan lagi menjadi lembaga yang memegang kedaulatan rakyat sehingga tugas dan kewenangannya sangat penting dan dibutuhkan setiap waktu. Saat ini tugas dan wewenang dari MPR sangat jarang dilaksanakan karena harus menunggu terpenuhinya keadaan tertentu sehingga MPR hanya terlihat seperti rapat gabungan antara DPR dan DPD dalam kondisi tertentu. Wewenang yang dimiliki oleh MPR bersifat ad hoc atau tidak tetap. Sebagai organ negara, lembaga MPR baru dapat dikatakan ada apabila fungsinya sedang bekerja (in action). Dari keempat kewenangan MPR, tidak ada satupun kewenangan tersebut yang dilakukan secara tetap. ${ }^{15}$ Secara periodik, MPR pasca amandemen UUD 1945, praktis hanya menjalankan tugas rutinitas lima tahunan sekali yaitu, melantik Presiden dan/atau Wakil Presiden. Tugas seremonial kenegaraan inipun membutuhkan waktu tidak kurang tidak lebih hanya satu setengah jam saja. ${ }^{16}$

Argumentasi kedua, MPR sebagai Joint session adalah dengan mengacu pada susunan keanggotaannya. Sebelum UUD NRI Tahun 1945, MPR memang tidak dapat dikatakan sebagai joint session. Hal ini disebabkan MPR memiliki komposisi keanggotaan tersendiri, yakni utusan daerah dan utusan golongan. Jadi, meskipun MPR juga mencakup anggota DPR, tetapi MPR juga memiliki anggota tetap, yang dianggap murni yaitu para utusan daerah dan utusan golongan. Keanggotaan tetap inilah yang menunjukan bahwa MPR adalah lembaga negara tersendiri yang bersifat permanen.

Namun demikian, UUD NRI Tahun 1945 telah membawa perubahan yang sangat signifikan dalam susunan keanggotaan MPR. Dengan dihilangkannya utusan golongan dan utusan daerah, MPR tidak lagi memiliki anggota tetap. Anggota MPR hanyalah anggota DPR dan DPD yang kemudian "berganti baju" sebagai anggota MPR dalam kegiatan tertentu saja. Diluar kegiatan tersebut, MPR tidak memiliki anggota tetap. Dalam pengertian MPR sebagai forum sidang gabungan adalah bahwa MPR tidak lagi sebagai lembaga yang mandiri. MPR hanya merupakan forum pertemuan antara dua lembaga Negara, yaitu DPR dan DPD.

Lalu bagaimana dengan keberadaan organ Ketua dan sekretaris Jenderal dalam kelembagaan MPR? Beberapa pakar menilai adanya Ketua dan Sekretaris Jenderal dalam susunan kelembagaan MPR, secara hakiki tidak membuat MPR sebagai lembaga permanen. Ketua dan Sekretaris Jenderal MPR ada karena pengaruh politis pada masa proses amandemen UUD 1945. ${ }^{17}$ Pada saat itu, masih ada perdebatan kamar

${ }^{14}$ Terjemahan bebas, Definitions, L. (2017, 11 Maret). Joint Session Law and Legal Definition. Dalam USLegal.

${ }^{15}$ Asshiddiqie, J. (2006b). Perkembangan dan Konsolidasi Lembaga Negara Pasca Reformasi. Jakarta: Konstitusi Press, hlm. 146.

${ }^{16}$ Nggilu, N. M. (2014). Op. Cit., hlm. 3.

${ }^{17}$ Asshiddiqie, J. (2006b). Op. Cit., hlm. 149. 
dalam parlemen, apakah sistem dua kamar atau tiga kamar. Mereka yang berpaham konservatif, tetap ingin mempertahankan MPR sebagai suatu lembaga permanen dengan dalih bahwa MPR adalah pencerminan sila ke-4 Pancasila, yaitu sebagai lembaga "permusyawaratan". Sehingga, mereka tidak ingin MPR hilang dengan mempertahankan adanya Ketua dan Sekretaris Jenderal sendiri. ${ }^{18}$ Keputusan ini juga terkait dengan tekanan politik yang diterima di masa kepemimpinan Megawati, dimana Beliau terdesak oleh tuntutan kepentingan elite politik agar semakin banyak jabatan publik sebagai bahan pembagian kekuasaan di antara mereka. ${ }^{19}$ Dengan demikian, keberadaan Ketua dan Sekretaris Jenderal MPR tidaklah menjadi justifikasi MPR sebagai lembaga permanen, melihat latar belakang pembentukannya sangat terpengaruh oleh tekanan politik dan hanya sebagai "topeng" agar MPR tidak hilang.

Berdasarkan argumentasi di atas banyak pihak yang kemudian menyatakan bahwa sistem perwakilan Indonesia adalah sistem dua kamar, karena MPR setelah amandemen UUD 1945 tidak lagi terdiri dari anggota DPR maupun utusan daerah serta utusan golongan, melainkan terdiri dari anggota DPR dan anggota DPD. Konstruksi sistem perwakilan dua kamar itu berawal dari pemikiran bahwa lembaga perwakilan yang ada di Indonesia itu tercermin dari dua lembaga perwakilan, yaitu DPR dan DPD. Hanya saja, sistem dua kamar yang digunakan di Indonesia kewenangannya masih terbatas atau dapat disebut sebagai sistem dua kamar yang lemah (soft bicameral), bahkan kewenangan terhadap halhal yang berkaitan dengan kebijakan strategis mengenai daerah, peran DPD masih juga terbatas, misalnya DPD tidak bisa menjalankan fungsi legislasi sebagaimana yang dimiliki DPR. ${ }^{20}$

Terlepas dari argumentasi yang ada, pandangan yang menilai MPR hanya sebagai join session seperti pada Kongres Amerika Serikat bukanlah pandangan yang populer. Pandangan lain yang menilai struktur lembaga perwakilan dengan sistem tiga kamar disampaikan antara lain oleh Jimly Asshiddiqie dan Bagir Manan. Menurut Jimly Asshiddiqie, sistem perwakilan Indonesia tidak dapat disebut sebagai sistem perwakilan dua kamar, ${ }^{21}$ akan tetapi sistem perwakilan tiga kamar. Dasar-dasar yang menguatkan pernyataan dari Jimly Asshiddiqie tersebut adalah: ${ }^{22}$

1. Susunan anggota MPR secara struktural mengalami perubahan karena ditiadakannya keberadaan utusan golongan yang mencerminkan prinsip keterwakilan fungsional dari unsur keanggotaan MPR. Jadi, keanggotaan MPR terdiri dari anggota DPR yang mencerminkan prinsip keterwakilan politik dan anggota DPD yang mencerminkan prinsip keterwakilan daerah;

\footnotetext{
${ }^{18}$ Ibid., hlm. 150.

${ }^{19}$ Ibid., hlm. 151.

${ }^{20}$ Marijan, K. (2019). Sistem Politik Indonesia: Konsolidasi Demokrasi Pasca Orde Baru. Jakarta: Kencana Prenada Media Group, hlm. 47.

${ }^{21}$ Asshiddiqie, J. (2009). Komentar Atas Undang-Undang Dasar Negara Republik Indonesia Tahun 1945. Jakarta: Sinar Grafika, hlm. 16.

${ }^{22}$ Yuhana, A. (2007). Sistem Ketatanegaraan Indonesia Pasca Perubahan UUD 1945: Sistem Perwakilan di Indonesia dan Masa Depan MPR RI. Bandung: Fokus Media, hlm. 65.
} 
2. MPR tidak lagi berfungsi sebagai "supreme body" yang memiliki kewenangan tertinggi dan tanpa adanya kontrol dari lembaga negara lain, sehingga kewenangannya pun mengalami perubahanperubahan yang mendasar;

3. Diadopsinya prinsip pemisahan kekuasaan (separation of power) secara tegas antara fungsi legislatif dan eksekutif dalam perubahan Pasal 5 Ayat 1 juncto Pasal 20 Ayat 1 dalam perubahan pertama UUD NRI Tahun 1945, yang kemudian dipertegas lagi dengan tambahan Pasal 20 Ayat 5 pada perubahan kedua UUD NRI Tahun 1945. Dengan adanya perubahan ini, maka UUD NRI Tahun 1945 tidak lagi menganut prinsip MPR sebagai "supremasi parlemen" dan tidak lagi dianutnya sistem pembagian kekuasaan (distribution of power) oleh lembaga tertinggi MPR ke lembaga-lembaga negara di bawahnya.

Hasil kajian dari sejumlah peneliti dan pengkaji Hukum Tata Negara Indonesia, UUD NRI Tahun 1945 justru menghasilkan sistem lembaga perwakilan tiga kamar yang menempatkan MPR sebagai kamar tersendiri dalam sistem lembaga perwakilan di Indonesia. Hal tersebut dikarenakan MPR terdiri atas anggota DPR dan anggota DPD (Pasal 2 Ayat 1 UUD NRI Tahun 1945). Bagir Manan menegaskan bahwa MPR menjadi wadah atau badan perwakilan tersendiri karena susunan keanggotaannya yang menyebutkan terdiri dari anggota-anggota DPR dan DPD. Dalam susunan lembaga perwakilan dua kamar menurut Bagir Manan pula, bukan anggota yang menjadi unsur. Dengan demikian maka MPR merupakan lembaga yang berdiri sendiri. Jadi dapat disebutkan UUD NRI Tahun 1945 tidak menempatkan lembaga MPR sebagai sidang gabungan atau joint session antara DPD dan DPR. ${ }^{23}$

Terlepas dari perdebatan yang ada, penulis sependapat dengan pandangan Jimly dan Bagir Manan bahwa UUD NRI Tahun 1945 telah membentuk lembaga perwakilan Indonesia menjadi sistem tiga kamar. Sistem ini secara teoritis tidak dikenal sehingga perlu penjelasan lebih lanjut mengenai asal muasal dan pertimbangannya. ${ }^{24}$ Adapun sebagai sebuah gagasan penyempurnaan bagi desain lembaga perwakilan di masa depan, mengacu pada hasil analisis perbandingan dan teori-teori yang ada, penulis mengusulkan beberapa hal sebagai berikut;

1. Di masa depan, desain lembaga perwakilan sebaiknya konsisten pada ide awal reformasi kelembagaan MPR yang menganut sistem dua kamar. Hal ini sejalan dengan apa yang ditulis oleh Tim Peneliti Pusat Studi Hukum dan Kebijakan pada tahun 2003, bahwa: ${ }^{25}$

\footnotetext{
${ }^{23}$ Isra, S. (2010). Pergeseran Fungsi Legislasi: Menguatnya Model Legislasi Parlementer dalam Sistem Presidensial di Indonesia. Jakarta: PT. Raja Grafindo Persada, hlm. 255.

${ }^{24}$ Selain Indonesia, Afrika Selatan tercatat pernah menerapkan model parlemen tiga kamar. Dalam pemilihan umum 1983, parlemen tiga kamar muncul untuk mengakomodasi penduduk dengan warna kulit tertentu, yang terdiri dari House of Assembly untuk kelompok kulit putih, House of Representatives untuk kulit berwarna, dan House of Delegates untuk kelompok orang Asia. Lihat Mochtar, Z. A. (2007, 11 - 13 Mei). Pengamaran Parlemen di Dalam Institusi Negara. Makalah dipresentasikan pada Pertemuan Pengajar Ilmu Tata Negara tentang Kelanjutan Amandemen Konstitusi, di Bukit Tinggi, Sumatera Barat.

${ }^{25}$ Editorial. (2000). Semua Harus Terwakili: Studi Mengenai Reposisi MPR, DPR, dan Lembaga Kepresidenan di Indonesia. Jakarta: Pusat Studi Hukum dan Kebijakan Indonesia, hlm. 41.
} 
“...adanya kebutuhan-kebutuhan di tingkat struktur ketatanegaraan menyebabkan gagasan mengenai lembaga perwakilan rakyat dua kamar sebagai jawaban yang tepat untuk merespon kebutuhan tersebut. Sebagai lembaga perwakilan rakyat, susunan kelembagaan MPR yang direkomendasikan adalah terdiri dari dua kelompok warganegara, yaitu: kelompok warga negara yan diwakili berdasarkan populasi tertentu penduduk, dan kelompok warganegara yang diwakili berdasarkan wilayah."

2. Sebagai konsekuensi dari Lembaga perwakilan dua kamar, sebaiknya MPR berfungsi sebagai forum pertemuan bersama atau join session antara kamar pertama dan kamar kedua, dan bukan sebagai lembaga negara yang berdiri sendiri. Dari segi ketatanegaraan hal ini akan berdampak pada efisiensi anggaran dan efektivitas kinerja dikarenakan tidak terjadi lagi perangkapan jabatan yang tidak perlu, semisal antara anggota DPR dan DPD yang merangkap sebagai anggota MPR sehingga berimplikasi pada insentif dan honorarium yang berganda, kewenangan yang tidak rutin, dan ketidakjelasan representasi. Sebagai sebuah join session, anggota DPR dan DPD hanya dikatakan sebagai anggota MPR ketika melaksanakan sidang gabungan dalam rangka membahas hal-hal yang bersifat istimewa dan khusus di luar kewenangan yang dimiliki oleh masing-masing lembaga. Agenda khusus tersebut sebagaimana yang diatur menjadi kewenangan MPR saat ini, seperti halnya melantik Presiden.

3. Keberadaan lembaga perwakilan dua kamar tersebut mesti didukung dengan perimbangan kekuasaan antara kamar pertama (the upper house) dan kamar kedua (the lower house). Keseimbangan ini baik dari segi filosofi sistem perwakilan yang diusung, maupun aspek kewenangan dan hubungan antar kedua kamar. Misalnya DPR sebagai kamar pertama mewakili representasi politik (political representation) sedangkan DPD harus menjamin adanya keterwakilan daerah (regional representation).

4. Aspek hubungan kelembagaan dan hubungan kewenangan juga harus diatur sedemikian rupa di bawah prinsip check and balances. Hal ini bertujuan agar tercipta "strong bicameral system" bahkan "perfect bicameral system". Hal ini akan dikemukakan secara lebih spesifik dalam uraian gagasan berikutnya.

5. Bahwa Konstitusi perlu menegaskan struktur lembaga perwakilan secara eksplisit dalam Pasal-pasalnya, atau setidaknya dalam penjelasan yang menjadi satu kesatuan dengan batang tubuh undangundang dasar.

\section{B. Perimbangan Kekuasaan antar Kamar dalam Parlemen}

Sebuah kisah menarik menceritakan tentang dua Founding Fathers Amerika Serikat, George Washington dan Thomas Jefferson, yang minum kopi bersama sambil memperdebatkan manfaat dari membagi kekuatan Kongres menjadi sistem dua kamar. Saat berdebat menentang Kongres 
dengan sistem dua kamar, Jefferson tiba-tiba mengatakan bahwa dia ingin menuangkan kopinya ke dalam cawan "untuk mendinginkannya". Hal ini ditanggapi oleh Washington, yang menyukai Kongres menggunakan sistem dua kamar dengan mengatakan, "Kami juga akan menuangkan undangundang kami ke dalam piring Senator, untuk mendinginkannya dulu". ${ }^{26}$

Dalam bukunya, C. F. Strong berani mengatakan bahwa kekuasaan legislatif di negara konstitusional modern dijalankan oleh lembaga perwakilan yang terdiri dari dua kamar, yang salah satu atau kedua kamar tersebut merupakan pilihan rakyat. ${ }^{27} \mathrm{Hal}$ ini diamini oleh Miriam Budiardjo yang menuliskan hampir setiap negara dengan susunan federal memilih sistem dua kamar karena satu kamar di antara kamar lainnya mewakili negara bagian. Sistem dua kamar juga kadang dianut oleh negara dengan susunan kesatuan. Pilihan negara kesatuan kepada struktur lembaga perwakilan sistem dua kamar adalah karena kamar yang satu diharapkan dapat mengimbangi dan membatasi kamar lainnya. Kamar kedua diharapkan dapat melaksanakan fungsi checks terhadap kamar pertama, sehingga diperoleh pencegahan akan timbulnya penyalahgunaan atau penyelewengan pelaksanaan kekuasaan negara.

Keberadaan MPR yang berubah kedudukan dan wewenangnya dalam UUD NRI Tahun 1945, sebetulnya dimaksudkan untuk mendukung diperkuatnya sistem pemerintahan presidensial Indonesia dan untuk menciptakan prinsip saling mengimbangi dan mengawasi (checks and balances) antar lembaga negara, sehingga diperlukan lembaga negara yang kedudukannya seimbang dan sederajat, tidak ada lembaga negara yang tertinggi. Termasuk dalam hal ini dengan menyusun format lembaga perwakilan dengan ciri dua kamar, yakni DPR yang mewakili kepentingan politik, dan DPD yang merepresentasikan kepentingan daerah.

Maka dari itu kemudian komposisi keanggotaan MPR berubah di dalam UUD NRI Tahun 1945. Menurut Pasal 2 Ayat 1 UUD NRI Tahun 1945, MPR terdiri atas anggota DPR dan anggota Dewan Perwakilan Daerah (DPD). Utusan daerah yang sebelumnya menjadi anggota MPR berubah menjadi sebuah lembaga negara tersendiri, yaitu DPD. Adanya DPD dimaksudkan agar keterwakilan daerah-daerah di Indonesia menjadi lebih maksimal. Ada beberapa asumsi atau pendapat yang mendasari perlunya keterwakilan daerah di lembaga perwakilan, antara lain: ${ }^{28}$

1. Agar ada keterkaitan budaya, sejarah, ekonomi, dan politik antara penduduk dengan daerah dan adanya penyebaran penduduk Indonesia yang tidak merata (sebagian besar tinggal di Pulau Jawa).

2. Untuk mewujudkan checks and balances antara lembaga negara agar tidak ada kesewenang-wenangan sebuah lembaga negara.

\footnotetext{
${ }^{26}$ Kaplan, D. S. (2015). An Introduction to the American Legal System, Government, and Constitutional. Deventer: Wolters Kluwer, hlm. 21.

${ }^{27}$ Strong, C. F. (2010). Konstitusi-Konstitusi Politik Modern: Studi Perbandingan tentang Sejarah dan Bentuk (D. S. Widowatie, Trans.). Bandung: Nusamedia, hlm. 11.

${ }^{28}$ Yuhana, A. (2007). Op. Cit., hlm. 129.
} 
3. Untuk menghindari adanya monopoli dalam pembuatan perundangundangan sehingga dapat dihasilkan sebuah undang-undang yang lebih baik.

Keberadaan tiga lembaga negara (MPR, DPR, dan DPD) sebagai lembaga perwakilan di Indonesia ini kemudian menimbulkan persoalan. Pengaturan di dalam konstitusi berimplikasi pada peran DPR sebagai lembaga legislatif yang diperkuat, kedudukan MPR yang bukan lagi sebagai lembaga negara tertinggi negara dan tugasnya hanya "sewaktuwaktu" saja dan tidak rutin, dan DPD yang kewenangannya sangat terbatas dalam hal legislasi, karena hanya bisa mengajukan, membahas, dan mengawasi rancangan undang-undang yang berkaitan dengan: ${ }^{29}$

1. Otonomi daerah;

2. Hubungan pusat dan daerah;

3. Pembentukan, pemekaran, dan penggabungan daerah;

4. Pengelolaan sumber daya alam dan sumber daya ekonomi lainnya;

5. Hal-hal yang berkaitan dengan perimbangan keuangan pusat dan daerah.

Kekuasaan MPR yang "berkurang” dalam UUD NRI Tahun 1945 justru berbanding terbalik dengan kekuasaan DPR. Jika dalam UUD 1945, DPR selalu terkooptasi dan seolah jinak kepada penguasa Orde Baru, maka UUD NRI Tahun 1945, DPR menjadi lembaga negara yang "super power" (legislative heavy) dengan kedudukan yang strategis dan hak yang "mewah". Setiap anggota DPR misalnya, dilengkapi dengan hak imunitas. ${ }^{30}$

Secara kelembagaan, DPR juga dapat menentukan seseorang untuk menjadi pejabat negara melalui fit and proper test sebelum pejabat negara tersebut terpilih dan dilantik oleh Presiden, seperti: Panglima Tentara Nasional Indonesia (TNI); Kepala Polri (Kapolri), Ketua Komisi Pemberantasan Korupsi (KPK), Ketua Ombudsman, Ketua Komisi Nasional Hak Asasi Manusia (Komnas HAM), Komisioner Komisi Pemilihan Umum (KPU), dan lain sebagainya. ${ }^{31} \mathrm{Hal}$ ini menunjukkan betapa besarnya pengaruh dan kekuasaan anggota DPR yang terlibat dalam hampir seluruh proses pengisian jabatan publik dan lembaga negara.

Sebagai dua kekuatan yang diharapkan saling mengawasi dan mengimbangi dalam sistem parlemen dua kamar, eksistensi serta peranan DPR dan DPD justru tidak seimbang. Bahkan ada yang mengatakan jika dibandingkan dengan DPR, DPD itu lembaga negara "antara ada dan tiada" dan ada pula yang menganggap sistem perwakilan dua kamar ini sesungguhnya adalah sistem perwakilan "satu setengah kamar" atau "quasi dua kamar". ${ }^{32}$

${ }^{29}$ Lihat ketentuan Pasal 22D ayat (1), (2), dan (3) UUD NRI Tahun 1945.

${ }^{30}$ Lihat ketentuan Pasal 80 huruff, dan Pasal 224 ayat (1), (2), dan (3) UU No. 17 Tahun 2014. Namun, hak imunitas itu tak berpengaruh jika anggota DPR terlibat tindak pidana khusus seperti korupsi, terorisme, dan kasus narkoba. Lihat Akuntono, I. (2014, 21 November). Anggota DPR: Hak Imunitas untuk Jaga Kehormatan Dewan. Dalam Kompas.com.

${ }^{31}$ Susanto, M., Prasetianingsih, R., \& Sungkar, L. (2018). Kekuasaan DPR dalam Pengisian Pejabat Negara dalam Sistem Ketatanegaraan Indonesia. Jurnal Penelitian Hukum De Jure, Badan Penelitian dan Pengembangan Hukum dan HAM, 18(1), hlm. 31.

${ }^{32}$ Marijan, K. (2019). Op. Cit., hlm. 47. 
Dari segi fungsi legislasi misalnya, DPD yang hanya dapat mengajukan rancangan undang-undang kepada DPR, ikut membahas rancangan undang-undang, serta memberikan pertimbangan rancangan undang-undang kepada DPR adalah sebuah fungsi legislasi yang tidak penuh. DPD dianggap sebagai salah satu "pembantu" DPR dalam fungsi legislasi. Jimly Asshiddiqie menyebut posisi DPD itu dengan colegislator. ${ }^{33}$ DPR sebagai legislator utama, sedangkan DPD, karena fungsi legislasinya yang tidak setara dengan DPR, berposisi sebagai lembaga penunjang (auxiliary organ) terhadap fungsi legislasi DPR. ${ }^{34}$

Dalam konteks seleksi jabatan publik, Peran DPD semakin kerdil dibandingkan dengan DPR jika dicermati dari sisi pemilihan calon untuk mengisi jabatan dalam lembaga negara. Misalnya, dalam pengisian anggota Badan Pemeriksa Keuangan, peran DPD hanya memberikan pertimbangan kepada DPR. Bahkan dalam pengisian jabatan lembaga negara lainnya, DPD tidak memiliki peran sama sekali. Contohnya, dalam pengisian jabatan Hakim Agung di MA, Hakim Konstitusi di Mahkamah Konstitusi, anggota Komisi Yudisial, dan lain-lain. Hal yang sangat kontras dengan kewenangan DPR yang dinilai sangat luas dan cenderung overweight.

Ada pendapat yang cukup menarik dari Stephen Sherlock, seorang peneliti dari Australian National University yang mengatakan bahwa, keberadaan lembaga perwakilan seperti DPD di Indonesia sebetulnya merupakan contoh yang tidak lazim dalam praktik lembaga perwakilan rakyat dengan sistem dua kamar, karena DPD merupakan kombinasi dari lembaga dengan kewenangan yang amat terbatas dan legitimasi tinggi. Menurut Saldi Isra, dengan kewenangan yang begitu terbatas itu pula sesungguhnya DPD tidak dapat dikatakan mempunyai fungsi legislasi, karena bagaimanapun juga fungsi legislasi sebenarnya harus dilihat secara utuh dan menyeluruh, yaitu dimulai dari proses pengajuan sampai menyetujui sebuah rancangan undang-undang menjadi undangundang. Dengan demikian sebetulnya hanya DPR sebagai lembaga perwakilan yang mempunyai fungsi legislasi secara utuh. DPD apalagi MPR tidak mempunyai fungsi legislasi sebagaimana dimiliki oleh DPR. ${ }^{35}$

Berdasarkan analisis sebelumnya, maka penulis merumuskan gagasan penyempurnaan sebagai berikut;

1. Perlu adanya reposisi dan penegasan mengenai kedudukan DPR dan DPD menjadi kamar pertama dan kamar kedua dalam sistem perwakilan dua kamar.

2. Perlunya Penguatan DPD dari segi fungsi dan peranan sebagai kamar kedua berdasarkan prinsip check and balance. Dalam aspek legislasi misalnya, DPD harus diberikan kewenangan yang setara dalam melakukan double check terhadap setiap rancangan Undang-undang

\footnotetext{
${ }^{33}$ Asshiddiqie, J. (2006a). Hukum Acara Pengujian Undang-Undang. Jakarta: Konstitusi Press, hlm. $30-31$.

${ }^{34}$ Ibid., hlm. 31.

${ }^{35}$ Isra, S. (2010). Op. Cit., hlm. 257. Adapun kewenangan yang terbatas dari DPD dapat dilihat dalam ketentuan Pasal 22D ayat (1), (2), dan (3) UUD NRI Tahun 1945, sedangkan legitimasi yang tinggi dari DPD dapat dilihat dalam ketentuan Pasal 22E ayat (2) dan (4) UUD NRI Tahun 1945.
} 
yang dibahas. Dengan demikian kewenangan tidak hanya sampai pada pengusulan, pembahasan dan memberikan pertimbangan, tetapi juga pada tahap persetujuan. Hal ini mengingat DPD membawa keterwakilan daerah yang sama pentingnya dengan DPR sebagai perwakilan politik. Pada hakikatnya dua-duanya sama-sama merepresentasikan kepentingan nasional sehingga seharusnya dapat saling bekerjasama, saling mengimbangi dan mengawasi.

3. Perlu menata ulang kewenangan khusus yang dimiliki oleh masingmasing lembaga di luar fungsinya sebagai anggota MPR. Misalnya penataan kewenangan DPR dalam hal pengisian jabatan publik. Lalu pemberdayaan lembaga DPD, misalnya dengan memberikan kewenangan pengawasan terhadap pelaksanaan pemerintahan daerah atau terhadap penggunaan anggaran pusat yang dialokasikan ke daerah.

\section{SIMPULAN DAN SARAN}

Adapun Gagasan Penyempurnaan bagi desain lembaga perwakilan Indonesia kedepannya, perlu dilakukan dua hal yaitu: Pertama, mempertegas struktur kelembagaan yang dipilih, apakah menganut sistem dua kamar atau tiga kamar. Dalam hal ini penulis menyarankan untuk konsisten dengan sistem dua kamar dengan mengubah MPR menjadi forum rapat bersama atau joint session dimana DPR dan DPD menjelma menjadi MPR untuk bertemu membahas hal yang sifatnya khusus dan istimewa. Dengan demikian akan terjadi efisiensi dan efektifitas dalam kinerja lembaga perwakilan. Hal ini karena MPR memiliki tugas dan kewenangan yang hanya periodik dan tidak rutin untuk berdiri sebagai lembaga tersendiri. Disamping itu, sistem dua kamar sudah cukup merepresentasikan keterwakilan politik dan daerah; Kedua, menyeimbangkan kedudukan dan peran antar kamar. Dalam hal ini DPR dan DPD perlu dilakukan reposisi dan penataan ulang terkait kewenangannya. Berdasarkan hasil analisis, DPR mendominasi DPD dalam struktur parlemen sehingga kedepannya perlu penguatan DPD sebagai the lower house baik dalam hal legislasi, penganggaran dan pengawasan agar dapat melakukan perimbangan dan pengawasan yang lebih efektif terhadap DPR sebagai the upper house.

\section{DAFTAR RUJUKAN}

Akuntono, I. (2014, 21 November). Anggota DPR: Hak Imunitas untuk Jaga Kehormatan Dewan. Dalam Kompas.com. Diakses dari https://nasional. kompas.com/read/2014/11/21/11403231/Anggota.DPR.Hak. Imunitas.untuk.Jaga.Kehormatan, pada tanggal 9 September 2019.

Asril, S. (2014, 29 September). MPR Ingin Amandemen UUD 1945, MPR Jadi Lembaga Tertinggi Negara dan Hidupkan GBHN.

Dalam Kompas.com. Diakses dari https://nasional.kompas. com/read/2014/09/29/15223701/MPR.Ajukan.Rekomendasi. Amandemen.UUD.19\%2045.MPR.Jadi.Lembaga.Tertinggi.Negara. dan.Hidupkan.GBHN, pada tanggal 23 September 2016.

Asshiddiqie, J. (2005). Konstitusi dan Konstitusionalisme Indonesia. Jakarta: Konstitusi Press. 
Pleno Jure, Vol. 9 (1), Rizki Ramadani, Gagasan Penyempurnaan Lembaga ...

Asshiddiqie, J. (2006a). Hukum Acara Pengujian Undang-Undang. Jakarta: Konstitusi Press.

Asshiddiqie, J. (2006b). Perkembangan dan Konsolidasi Lembaga Negara Pasca Reformasi. Jakarta: Konstitusi Press.

Asshiddiqie, J. (2009). Komentar Atas Undang-Undang Dasar Negara Republik Indonesia Tahun 1945. Jakarta: Sinar Grafika.

Bachmid, F., Sampara, S., \& Husen, L. O. (2018). The Rights of the Constitutional Court's Decision on the House of Representatives' Representatives about the President's Prospective and/or the President's Vice Representatives According to the State Basic Law of the Republic of Indonesia. Journal of Humanities and Social Science, IOSR, 23(10), hlm. $43-61$.

Definitions, L. (2017, 11 Maret). Joint Session Law and Legal Definition. Dalam USLegal. Diakses dari https://definitions.uslegal.com/j/jointsession/, pada tanggal 21 Oktober 2019.

Editorial. (2000). Semua Harus Terwakili: Studi Mengenai Reposisi MPR, $D P R$, dan Lembaga Kepresidenan di Indonesia. Jakarta: Pusat Studi Hukum dan Kebijakan Indonesia.

Efriza. (2014). Studi Parlemen: Sejarah, Konsep, dan Lanskap Politik Indonesia. Malang: Setara Press.

Falaakh, M. F. (2002, 19 April). Metamorfosis MPR (Teka-Teki Parlemen Berkamar Tiga), dalam Harian Kompas.

Isra, S. (2004). Penataan Lembaga Perwakilan Rakyat: Sistem Trikameral di Tengah Supremasi Dewan Perwakilan Rakyat. Jurnal Konstitusi, Mahkamah Konstitusi RI, 1(1).

Isra, S. (2010). Pergeseran Fungsi Legislasi: Menguatnya Model Legislasi Parlementer dalam Sistem Presidensial di Indonesia. Jakarta: PT. Raja Grafindo Persada.

Kaplan, D. S. (2015). An Introduction to the American Legal System, Government, and Constitutional. Deventer: Wolters Kluwer.

Kusumaatmadja, M. (2002). Konsep-Konsep Hukum dalam Pembangunan (O. Salman \& E. Damian Eds.). Bandung: PT. Alumni.

Marijan, K. (2019). Sistem Politik Indonesia: Konsolidasi Demokrasi Pasca Orde Baru. Jakarta: Kencana Prenada Media Group.

Mochtar, Z. A. (2007, 11 - 13 Mei). Pengamaran Parlemen di Dalam Institusi Negara. Makalah dipresentasikan pada Pertemuan Pengajar Ilmu Tata Negara tentang Kelanjutan Amandemen Konstitusi, di Bukit Tinggi, Sumatera Barat.

Nggilu, N. M. (2014). Hukum dan Teori Konstitusi (Perubahan Konstitusi yang Partisipatif dan Populis). Yogyakarta: UII Press.

Nggilu, N. M. (2017, September). "Membaca” Kedudukan dan Kewenangan MPR dalam Sistem Ketatanegaraan Indonesia (Sebuah Kontemplasi Menuju Amandemen Kelima). Makalah dipresentasikan pada Seminar Nasional, diselenggarakan oleh Majelis Permusyawaratan Rakyat RI, di Jakarta. 
Putri, B. U. (2019, 8 Agustus). Anggota MPR: Ada yang Ingin Amandemen UUD 1945 ke Versi Pertama. Dalam Tempo.co. Diakses dari https:// nasional.tempo.co/read/1233546/anggota-mpr-ada-yangingin-amandemen-uud-1945-ke-versi-pertama, pada tanggal 23 Desember 2019.

Risnain, M., \& Karyati, S. (2017). Menimbang Gagasan Perubahan Konstitusi dan Tata Cara Perubahan Konstitusi Republik Indonesia 1945. Jurnal Ius: Kajian Hukum dan Keadilan, Universitas Mataram, 5(1), hlm. 110 - 118. doi: http://dx.doi.org/10.29303/ius.v5i1.445

Rohmat, A. M. (2016). Kedudukan dan Kewenangan Majelis Permusyawaratan Rakyat dalam Era Reformasi. Jurnal Pembaharuan Hukum, Universitas Islam Sultan Agung, 3(2), hlm. 181 - 190. doi: http://dx.doi.org/10.26532/jph.v3i2.1408

Strong, C. F. (2010). Konstitusi-Konstitusi Politik Modern: Studi Perbandingan tentang Sejarah dan Bentuk (D. S. Widowatie, Trans.). Bandung: Nusamedia.

Susanti, B. (2009). Lembaga Perwakilan Rakyat Trikameral, Supremasi DPR dan Sempitnya Ruang Demokrasi Perwakilan: Isi dan Implikasi UU Susduk dan Cermin Carut Marutnya Konstitusi. In A. R. M. \& L. Bakry (Eds.), Politik dan Pemerintahan Indonesia (hlm. 440 - 456). Jakarta: Masyarakat Ilmu Pemerintahan Indonesia.

Susanto, M., Prasetianingsih, R., \& Sungkar, L. (2018). Kekuasaan DPR dalam Pengisian Pejabat Negara dalam Sistem Ketatanegaraan Indonesia. Jurnal Penelitian Hukum De Jure, Badan Penelitian dan Pengembangan Hukum dan HAM, 18(1), hlm. 23 - 41. doi: http:// dx.doi.org/10.30641/dejure.2018.V18.23-41

Undang-Undang Dasar Tahun 1945.

Undang-Undang Dasar Negara Republik Indonesia Tahun 1945.

Undang-Undang Republik Indonesia Nomor 17 Tahun 2014 tentang Majelis Permusyawaratan Rakyat, Dewan Perwakilan Rakyat, Dewan Perwakilan Daerah, dan Dewan Perwakilan Rakyat Daerah. Lembaran Negara Republik Indonesia Tahun 2014 Nomor 182. Tambahan Lembaran Negara Republik Indonesia Nomor 5568.

Widayati, W. (2015). Sistem Parlemen Berdasarkan Konstitusi Indonesia. Masalah-Masalah Hukum, Universitas Diponegoro, 44(4), hlm. 415 424. doi: https://doi.org/10.14710/mmh.44.4.2015.415-424

Widayati, W., Absori, A., \& Azhari, A. F. (2014). Rekonstruksi Kedudukan Ketetapan MPR dalam Sistem Ketatanegaraan Indonesia. Media Hukum, Universitas Muhammadiyah Yogyakarta, 21(2), hlm. 264 278.

Yuhana, A. (2007). Sistem Ketatanegaraan Indonesia Pasca Perubahan UUD 1945: Sistem Perwakilan di Indonesia dan Masa Depan MPR RI. Bandung: Fokus Media. 